\title{
Validity and Reliability Test of Four-Meter Gait Speed on Six Meter Track for Indonesian Adults
}

\author{
Nury Nusdwinuringtyas, ${ }^{1}$ Tresia Fransiska, ${ }^{1}$ Peggy Sunarjo, ${ }^{1}$ Kevin Triangto, ${ }^{1}$ Sopiyudin Dahlan ${ }^{2}$ \\ ${ }^{1}$ Department of Physical Medicine and Rehabilitation, Faculty of Medicine Universitas Indonesia/Dr. Cipto \\ Mangunkusumo General Hospital, Jakarta, Indonesia, ${ }^{2}$ Epidemiology Indonesia
}

\begin{abstract}
Walking is an essential component of daily life and studies have shown the growing number of clinicians performing walking tests in their daily practice. This study is aimed to assess the validity and reliability of the Four-Meter Gait Speed (4MGS) test for healthy Indonesian adults (Mongoloid race). Data collection were conducted at the Rehabilitation Department of Dr. Cipto Mangunkusumo General Hospital during the period of August 2016 to March 2017. Two observers and two trials were involved in measuring the gait speed in the 4MGS test with a 6 meter track. All accumulated data were analyzed for validity using the Bland-Altman test, while test re-test reliability was done using Cronbach's alpha for internal consistency. Sixty-one subjects were involved in this study. There were no significant differences in inter-trial comparison from both observers $(\mathrm{P}=0.262$ and $\mathrm{P}=0.954)$. Similarly, intra-observer walking speed comparison in both trials were also not significantly different $(\mathrm{P}=0.117$ and $\mathrm{P}=0.869)$. The intraclass correlation coefficient (ICC) value between the first and second tests from observer I was 0.839 (Cronbach Alpha,0.911) while the value for observer II was 0.902 (Cronbach Alpha, 0.948). The ICC value between observer I and II in the first trial was 0.906 (Cronbach Alpha, 0.950); whereas the second trial demonstrated a value of 0.890 (Cronbach Alpha, 0.941). Thus, the 6 meter track 4MGS has a good validity and reliability for healthy Indonesian adults. It is expected that the walking speed from this study can be used for Mongoloid race living in other countries and the 4MGS can become an alternative speed-based walk test, especially during COVID-19 pandemic, due to its practicality in measuring functional capacity in a shorter duration.
\end{abstract}

Keywords: 4MGS, 6 meters track, mongoloid race

\section{Validitas dan Reabilitas Uji Jalan Empat Meter dengan Jalur Enam Meter pada Dewasa Indonesia}

\begin{abstract}
Abstrak
Berjalan merupakan komponen penting dari kehidupan sehari-hari, banyak penelitian mengenai uji jalan dalam keseharian mereka. Penelitian ini bertujuan mengetahui apakah 4MGS dapat sah dan digunakan pada orang sehat dewasa (ras mongoloid). Data didapatkan di Rumah Sakit Cipto Mangunkusumo selama periode Agustus 2016 sampai Maret 2017. Dua pengamat dan dua percobaan dilakukan untuk mengukur kecepatan gait pada 4MGS dengan jalur sepanjang 6 meter. Seluruh data dianalisis dengan bland-altman untuk uji keabsahan, sedangkan untuk uji keandalan menggunakan crohnbach's alpha. Terdapat 61 orang yang terlibat. Tidak ada perbedaan yang signifikan dalam perbandingan antar-percobaan kedua pengamat $(\mathrm{P}=0,262$ dan $\mathrm{P}=0,954)$. Demikian pula, perbandingan kecepatan berjalan intrapengamat pada kedua percobaan tidak berbeda secara signifikan $(\mathrm{P}=0,117$ dan $\mathrm{P}=0,869$ ). Nilai koefisien korelasi intrakelas (ICC) antara tes pertama dan kedua dari pengamat I adalah 0,839 dengan Cronbach Alpha 0,911; pengamat II adalah 0,902 dengan Cronbach Alpha 0,948. Nilai ICC antara observer I dan II pada uji coba pertama adalah 0,906 dengan Cronbach Alpha 0,950; sedangkan yang kedua adalah 0,890 dengan Cronbach Alpha 0,941. Lintasan 4MGS 6 meter memiliki validitas dan reliabilitas yang baik pada orang dewasa Indonesia yang sehat. Diharapkan kecepatan berjalan pada penelitian ini dapat digunakan di negara lain ras Mongoloid. 4MGS dapat menjadi alternatif tes jalan kaki berbasis kecepatan terutama di masa pandemi COVID-19 karena kepraktisannya dalam mengukur kapasitas fungsional dengan durasi yang lebih singkat.
\end{abstract}

Kata kunci: 4MGS, jalur 6 meter, ras mongoloid

Corresponding Author: Nury Nusdwinuringtyas, Department of Physical Medicine and Rehabilitation, Faculty of Medicine Universitas Indonesia/Dr. Cipto Mangunkusumo General Hospital Jakarta, Indonesia, Email: nury_nus@yahoo.com 


\section{Introduction}

Walking is an essential component of daily life, studies had shown the growing prevalence of clinicians performing walking tests in their daily practice. ${ }^{1}$ Walking has been proposed to effectively evaluate functional capacity as it requires a complex ensemble of cardiorespiratory, musculoskeletal, neuromuscular systems that are simultaneously activated during the walking process., ${ }^{2,3}$ Therefore, it could be implied that walking test is widely applicable in cardiorespiratory and neuromusculoskeletal disorders. ${ }^{4}$

Along the years, the six-minute walk test (6MWT) was proven to be the most applicable, hence it is widely used. A long track from the original American Thoracic Society (ATS) protocol has been adapted in Indonesia in a shorter track with good validity and reliability. ${ }^{5}$

However, there is another distance-based walk test based, namely the four-meter gait speed test (4MGS) with gait speed as their primary outcome. ${ }^{6,7}$ Although both are classified as walk test, they have different outcomes in which the outcome of the 6MWT is the walking distance. ${ }^{8,9}$ It can be deduced that both tests have demonstrated walking speed are their basic measurement. Compatibility between 6MWT and 4MGS has already been obtained. ${ }^{10}$

This study aims to assess the validity and reliability of 4MGS test in healthy Indonesian adults (Mongoloid). Indonesia is part of the Mongoloid race thus it is expected that this study result can give a valid and reliable test for another country with Mongoloid races.

\section{Methods}

The study was conducted after obtaining permission from the University of Indonesia's
Health Study Ethics committee, numbered 64 /UN2.Ft/ETIK/2016. The Data collection of this study were conducted at Departement of Rehabilitation of Dr. Cipto Mangunkusumo General Hospital during the period of August 2016 to March 2017. Purposive sampling was used to get the sample fot this study. Inclusion criteria were aged 18-50 years old, subject with sedentary lifestyle. Indonesia with Indonesia parent, Body Mass Index (BMI) 18.50 to 24.99. The exclusion criteria were people with imbalanced, having cardiovascular history, problems on extremities. The outcome of this study was walking speed for 4MGS as obtained by two observers. Each measurement was done two times by two independent observers. The second measurement was done after the first measurement and the results were compared. In this report, 4 MGS used six meters track, as it is more applicable in clinical setting. The six-meter track consisted of a four-meter track, preceded by a one-meter acceleration track, followed by another one-meter deceleration track (Figure 1). Lastly, the agreement test were done between both inter- and intra-rater.

Agreement test was done by using BlandAltman analysis. Bland-Altman analysis test is an agreement test that reports difference and limit of agreement descriptively without determining $\mathrm{p}$ value. In this test, the measurement scale must be the same (the numbers listed on the $\mathrm{X}$ and $Y$ axes must be the same) then a horizontal straight line drawn as a limit of agreement. If the scatter is closer to the limit of agreement it was considered appropriate. ICC interpretation can be categorized into: <0.50: poor reliability, 0.50-0.75: moderate reliability, 0.75-0.9: good reliability,> 0.9: excellent reliability. ${ }^{11}$

Next, the tests results were carried out for reliability assessments using the Cronbach Alpha test. Cronbach Alpha value was measured to show consistency in this study and was

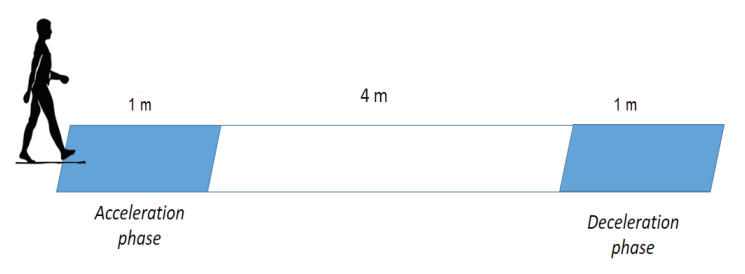

Figure 1 Four Meter Gait Speed at 6 Meters Track 
Table 1 Subjects Characteristics $(n=61)$

\begin{tabular}{lccc}
\hline \multicolumn{1}{c}{ Variable } & Mean & SD & P value* $^{*}$ \\
\hline Age (year) & & & \\
$\quad$ Male & 26.25 & 4.55 & 0.008 \\
$\quad$ Female & 27.54 & 4.91 & \\
BMI (kg/m²) & & & \\
$\quad$ Male & 21.41 & 1.83 & 0.667 \\
$\quad$ Female & 21.65 & 1.82 & \\
FEV (liter/min) & & & \\
$\quad$ Male & 3.69 & 0.42 & $<0.001$ \\
$\quad$ Female & 2.60 & 0.49 & \\
FVC (liter/min) & & & \\
$\quad$ Male & 3.41 & 0.42 & $<0.001$ \\
$\quad$ Female & 2.36 & 0.49 & \\
FEV $\%$ & & & \\
$\quad$ Male & 94.03 & 9.88 & 0.710 \\
Female & 96.72 & 13.35 & 0.536 \\
\hline
\end{tabular}

*Independent sample T-test

conducted repeatedly. Cronbach Alpha value of $>0.6$ indicated a good level of reliability, or in another word dependable.

\section{Results}

This study compared the walking speed of 4 MGS on the six-meter track as a validity and reliability test. The results of this study are presented in the form of tables and graphs.

Table 1 showed descriptive data which was a description of the subject's basic data. The subjects were 61 people consisting of 28 males and 33 females. From these data, the average age of men was $26.25( \pm 4.55)$ years old, while women was $27.54( \pm 4.91)$ years old. The mean BMI for men was $21.41( \pm 1.83) \mathrm{kg} / \mathrm{m}^{2}$ while women was $21.65( \pm 1.82) \mathrm{kg} / \mathrm{m}^{2}$. The value of lung capacity was included in this table, because lung capacity was also a requirement for subject acceptance and needed to be conveyed to ensure lung capacity was normal. In this study, a higher $F E V_{1}$ value was found in men compared to women, for men $3.69( \pm 0.42) \mathrm{l} / \mathrm{m}$, while for women $2.60( \pm 0.49) \mathrm{l} / \mathrm{m}$ and they were seen to be significantly different $(\mathrm{p}<0.001)$. Similar values also follow the trend in FVC, being significantly higher in males. On the other hand, $\mathrm{FEV}_{1} \%$, was also higher in males but yet were not significantly different.

Table 2 showed the results of the walking speed of the inter-rater 4MGS on the six meter track. The measurement results were carried out by two observers (Observer I and Observer II) with two-time observations, then the existing travel time was averaged and then entered into the speed formula. In the first test, the results of walking speed obtained by observer I was 2.028 $\mathrm{m} / \mathrm{s}$ and observer II was $1.991 \mathrm{~m} / \mathrm{s}$ with the results of the paired-t test analysis $p=0.262$. In the second test, the travel time for observer I was $1.996 \mathrm{~m} / \mathrm{s}$ and observer II was $1.995 \mathrm{~m} / \mathrm{s}$ with

Table 2 Speed of Four Meter Gait Speed Inter-rater on Six Meters Track (n=61)

\begin{tabular}{llllll}
\hline & Variable & $\begin{array}{l}\text { Mean } \\
(\mathbf{m} / \mathbf{s})\end{array}$ & SD & $\begin{array}{c}\text { CI 95\% } \\
\text { Minimum- } \\
\text { Maximum }\end{array}$ & P value* \\
\hline \multirow{2}{*}{$\mathbf{1}^{\text {st }}$ test } & $1^{\text {st }}$ Observer & 2.028 & 0.281 & $-0.028-0.102$ & 0.262 \\
\multirow{2}{*}{$2^{\text {nd }}$ test } & $2^{\text {nd }}$ Observer & 1.991 & 0.246 & & \\
& $1^{\text {st }}$ Observer & 1.996 & 0.226 & $-0.053-0.056$ & 0.954 \\
\hline
\end{tabular}

*Paired-sample T test

Table 3 Intra-rater of Walking Speed From Four Meter Gait Speed on Six Meters Track (n=61)

\begin{tabular}{|c|c|c|c|c|c|}
\hline \multicolumn{2}{|c|}{ Variable } & \multirow{2}{*}{$\begin{array}{l}\text { Mean } \\
(\mathrm{m} / \mathrm{s})\end{array}$} & \multirow{2}{*}{$\begin{array}{c}\text { SD } \\
0.281 \\
0.226\end{array}$} & \multirow{2}{*}{$\begin{array}{c}\text { CI 95\% } \\
\text { Minimum- } \\
\text { Maximum }\end{array}$} & \multirow{2}{*}{$\begin{array}{c}\text { P value* } \\
0.177\end{array}$} \\
\hline $1^{\text {st }}$ Observer & $\begin{array}{l}1^{\text {st }} \text { test } \\
2^{\text {nd }} \text { test }\end{array}$ & & & & \\
\hline $2^{\text {nd }}$ Observer & $\begin{array}{l}1^{\text {st }} \text { test } \\
2^{\text {nd }} \text { test }\end{array}$ & $\begin{array}{l}1.991 \\
1.994\end{array}$ & $\begin{array}{l}0.246 \\
0.261\end{array}$ & - 0.048-0.041 & 0.869 \\
\hline
\end{tabular}

*Paired-sample T test 
N Nusdwinuringtyas et al: Validity and Reliability Test of Four-Meter Gait Speed on Six Meter Track for Indonesian Adult

Table 4 Validity and Reliability on Inter-rater dan Intra-rater Speed Test

\begin{tabular}{lccc}
\hline & ICC & CI 95\% & Cronbach Alpha \\
\hline $1^{\text {st }}$ Intra-rater Observer & 0.839 & $0.745-0.900$ & 0.911 \\
$2^{\text {nd }}$ Intra-rater Observer & 0.902 & $0.842-0.940$ & 0.948 \\
$1^{\text {st }}$ Inter-rater test & 0.906 & $0.848-0.942$ & 0.950 \\
$2^{\text {nd }}$ Inter-rater test & 0.890 & $0.824-0.933$ & 0.941 \\
\hline
\end{tabular}

the results of the paired t test analysis $\mathrm{p}=0.954$

Table 3 showed the results of the walking speed of the intra-rater four meter gait speed on the six meters track. On observer I, the results of the running speed in the first test was 2.028 $\mathrm{m} / \mathrm{s}$ and the second test was $1.996 \mathrm{~m} / \mathrm{s}$ with the results of the paired test analysis $\mathrm{p}=0.117$. On observer II, the results of the travel time in the first test were $1.991 \mathrm{~m} / \mathrm{s}$ and the second test was $1.994 \mathrm{~m} / \mathrm{s}$ with the results of the paired test analysis $\mathrm{p}=0.869$.

Table 4 showed the validity and reliability of the inter-rater and intra-rater walking speed. On intra-rater of observer I, ICC values obtained in the first test and the second test was 0.839, with the value of Cronbach Alpha 0.911. On intrarater of observer II, the ICC value in the first test and the second test was 0.902 , with the value of Cronbach Alpha 0.948. Furthermore, on the first observation inter-rater, ICC scores for observer I and observer II was 0.906, with Cronbach Alpha 0.950. On the second observation inter-rater, ICC value for observer I and observer II was 0.890, with the value of Cronbach Alpha 0.941.

The mean differential value was 0.032 with standard deviation of 0.181 . A calculation was then carried out using the formula to find the

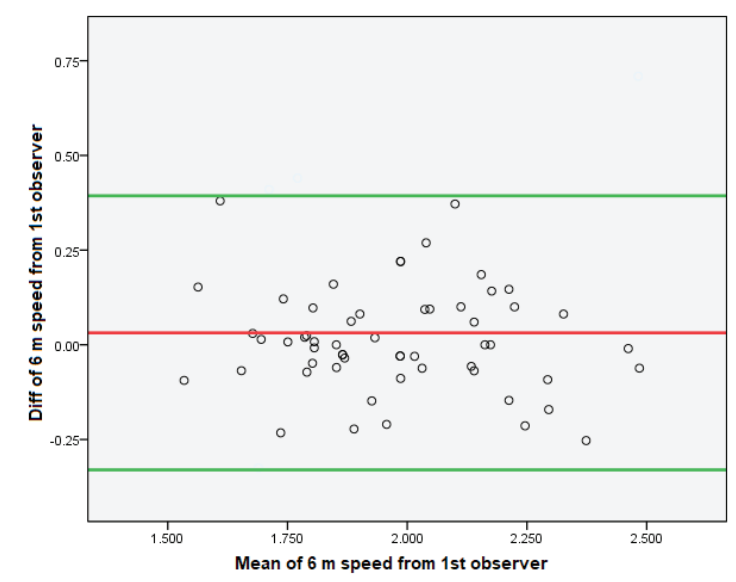

Figure 2 Bland Altman Agreement Speed Test from $1^{\text {st }}$ Observer limit of agreement which resulted in maximum limit of agreement of 0.393 and minimum limit of agreement of -0.330 .

While Figure 2 showed Bland Altman agreement of the speed test obtained by observer II. The mean differential value was -0.004 with standard deviation of 0.174 . Limit of agreement was formulated and the results were maximum limit of agreement of 0.344 and minimum limit of agreement of -0.351 .

\section{Discussion}

There are several modalities available for the objective evaluation of functional exercise capacity, ${ }^{1}$ such as stair climbing, $6 \mathrm{MWT}^{5}$, and a shuttle-walk test ${ }^{12}$. Six minute walk test is one of simple example to know activity performed daily living. ${ }^{5}$ Based on ATS statement, 6MWT requires a long track around $100 \mathrm{ft}^{\text {hallway }}{ }^{1}$ so that makes 6MWT quite difficult to do because it requires long path .1,5 Therefore, previous Nury's study on compatibility test between the 6MWT and four meter walking test made a 4MGS for an alternative to 6MWT.

Four MGS is one of the time based walk test

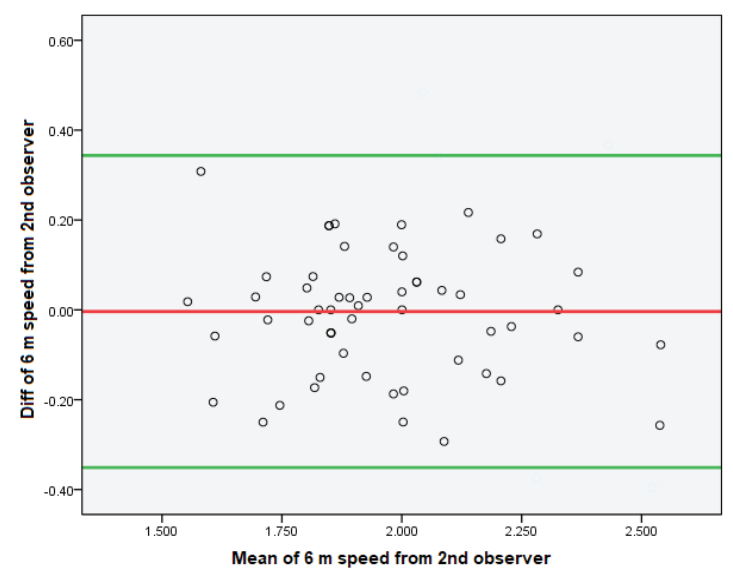

Figure 3 Bland Altman Agreement Speed Test from $2^{\text {nd }}$ Observer 
method that can be done to assess walking speed. ${ }^{13} \mathrm{~A}$ 4MGS track is considered to be optimal enough to assess walking speed and capable of being applied to daily clinical practice. ${ }^{7}$ This test assessment only requires a straight line without obstacles with a flat floor with a track mark and stopwatch. ${ }^{14}$ Non-professional staff can also be easily trained to carry out this test. ${ }^{6}$ The 4MGS test is conducted at the individual's usual pace over a short track with the only objective of obtaining a measure of physical performance under comfortable conditions. ${ }^{15}$

In the results of Nury's study on compatibility test between the 6MWT and 4MGS, it was demonstrated that 4 MGS could be an option to assess functional capacity in daily living. Previous studies also used six- and eight-meters track for 4MGS. It turned out that there was no difference between six and eight meters. Therefore, this study assessed the validity and reliability of the six meter road test track at $4 \mathrm{MGS}{ }^{5}$

In the setting of telerehabilitation, a study had shown that patients' self-recording using their handheld mobile devices placed on a fixed stand, have good validity and reliability despite lower bandwidth and frame rate ${ }^{16}$ Additionally, the corona virus disease 2019 (COVID-19) have been shown to significantly affect cardiorespiratory endurance, hence affecting activity and participation. ${ }^{17}$ Therefore in this pandemic era, gait speed monitoring through 4MGS is a feasible option for controlled evaluation cardiorespiratory endurance. This would as well as provide patients with a feeling of achievement over the functional capacity training, which was effectively proven for pulmonary disorders. ${ }^{18}$

Pulmonary values were seen to be higher in males, but since there were no significantly different values in gait speed between gender, it appeared that pulmonary values may not directly correlate to gait speed. Other studies had shown that in the long run, pulmonary values may correlate closely to 6MWT distance, thus indicating gait speed that may not correlate directly to sustainability over the 6 minute duration. ${ }^{19}$ However, it has been established that 4MGS portrays the average speed of 6MWT, hence it would portray steady state speed, as required in a submaximal exercise testing.

Table 2 showed the results of the walking speed inter-rater 4MGS on the six-meter track. This observation was done by two observers (Observer I and Observer II) with two times observations From the comparison of the first and second tests conducted by the two observers, $\mathrm{p}$ values of 0.262 and 0.954 were obtained respectively. It was concluded that there were no differences in the walking speed of the fourmeter inter-rater test between the two tests.

The same result in Table 3, showing the results of the intra-rater walking speed test of fourmeter gait speed on the six-meter track. Unlike the inter-rater, intra-rater tests compared the first and second tests on each observer. $\mathrm{P}$ value for first observer and second observer were 0.117 and 0.869 respectively. ( $p$ value $>0.05$ ) It was concluded that the walking speed of the 4MGS test in those two tests was not different.

This study conducted a test and retest between two observers which was written as inter-rater and intra-rater in this article. This repetition method in comparative studies was needed, but not enough, conditions for agreement between methods. If one or both methods did not generate repeated results, the assessment of agreement between methods was considered meaningless. Therefore we decided to do a Bland Altmant agreement test. ${ }^{20}$

Figure 1 and 2 demonstrated the mean difference and limit of agreement of this study. However, there has not been any prior study (to the authors' knowledge) on the inter-rater and intra-rater agreement according to the graphs. For that reason, this agreement test could not yet to be concluded as acceptable. ${ }^{20}$

In Table 4, the values of intraclass correlation coefficient (ICC) and Cronbach Alpha were obtained. Calculation of inter-rater and intrarater can also use intraclass correlation coefficient (ICC), where the reliability estimation method used a rating instrument that produces ordinal data. Intraclass correlation coefficient has been widely used in conservative care medicine to evaluate inter-rater, test-retest, and intra-rater reliability. ${ }^{21}$ All ICC values in table were $>0.75$. Then, Cronbach's Alpha test is one way to measure the strength of consistency. In table 4 the results of Crobach alpha are obtained on the inter-rater and the intra-rater test is obtained $>0.9$. if the result $>0.9$ means excellent consistency. Thus, the ICC in table 4 found good reliability on the $1^{\text {st }}$ observer intra-rater and $2^{\text {nd }}$ inter-rater test, and excellent reliability for the $2^{\text {nd }}$ intra-rater observer and $1^{\text {st }}$ inter-rater test.

In accordance with Kim et al on the study of gait speed reliability and validity with different walking pace and distance against general health, physical function and chronic in aged adults, this study has done similarly. ${ }^{7}$ In the final result, the study had obtained intraclass correlation coefficient (ICCs) to examine testretest reliability of variant walking distances 
(4, 6 and 10 meters). For the result, 4, 6, and 10 meters had good-excellent reliability for estimating physical function. ${ }^{7,14}$

This study showed a discrepancy in the mean rate speed in comparison with Bohannon et al. ${ }^{22}$ The later study was conducted in Caucasian population, differ from the population of the present study. Results from this study had shown a discrepancy in the mean rate speed compare with other similar age group studies by Bohannon and Wang. All these lead to the suggestive possibility of anthropometric differences in between Mongoloid and Caucasian race.

Further study about 4MGS is warranted with a larger population especially in many countries of Mongoloid race to prove that every race has its own standard values. Further study is also needed to determine the cut of point in once measurement especially in people with morbid or disability and to determine the minimal clinically dependent (MCID) score.

Four-MGS has several track options to do this test. Four-MGS on the 6-meter track has the results of good validity and reliability. This study is expected to be used as a reference to assess the daily functional capacity by carrying out a test that is easier to do with the same good results. This study also shows that four-MGS on the 6 meters track has a good validity and reliability to assess the daily functional capacity in Mongoloid race.

This validity and reliability study were based on the walking speed that conducted on Indonesian as Mongoloid race. Additionally, the validity and reliability of 4MGS could effectively be translated to daily telerehabilitation setting, especially during the pandemic era. It is expected that gait speed in this study can be used in another country of Mongoloid race with the same good result.

\section{References}

1. American Thoracic Society (ATS). Erratum: ATS statement: guidelines for the sixminute walk test. Am J Respir Crit Care Med. 2016;193(10):1185.

2. Wong PF, Chan EY, Ng DK, Kwok KL, Yip AY, Leung SY. Correlation between 6-min walk test and cardiopulmonary exercise test in Chinese patients. Pediatr Respirol Crit Care Med. 2018;2:32-5.

3. Middleton A, Fritz SL, Lusardi M. Walking Speed: the functional vital sign. J Aging Phys.
2015;23(2):314-22.

4. Morse CI, Bostock EL, Twiss HM, Kapp LH, Orme P, Jacques MF. The cardiorespiratory response and physiological determinants of the assisted 6-minute handbike cycle test in adult males with muscular dystrophy. Muscle Nerve. 2018;58(3):427-33.

5. Nusdwinuringtyas N, Alwi I YF. Kesahihan dan keandalan uji jalan 6-menit pada lintasan 15-meter. Media Litbangkes. 2018;28(2):131-6.

6. Unver B, Baris RH, Yuksel E, Cekmece S, Kalkan S, Karatosun V. Reliability of 4-meter and 10-meter walk tests after lower extremity surgery. Disabil Rehabil. 2017;39(25):2572-6.

7. Kim H, Park I, On L. The reliability and validity of gait speed with different walking pace and distances against general health, physical function, and chronic disease in aged adults. J Exerc Nutr Biochem. 2016;20(3):46-50.

8. Nusdwinuringtyas N. Six minute walking distance cut-off point in Indonesian (Mongoloid) population. J Indon Med Assoc. 2018;68(8):389-94.

9. Nusdwinuringtyas N. Six minute walk test as a measurement tool for functional capacity. J Indon Med Assoc. 2018;68(4):159-60.

10. Nusdwinuringtyas N, Fransiska T. Compatibility test between the six minutes walking test and four meter walking test. Ann Phys Rehabil Med. 2018;61(2018):e547.

11. Koo TK, Li MY. A Guideline of selecting and reporting intraclass correlation coefficients for reliability research. J Chiropr Med. 2017; 16(4):346.

12. Parreira VF, Janaudis-Ferreira T, Evans RA, Mathur S, Goldstein RS, Brooks D. Measurement properties of the incremental shuttle walk test: a systematic review. Chest. 2014;145(6):1357-69.

13. Karpman C, Lebrasseur NK, Depew ZS, Novotny PJ, Benzo RP. Measuring gait speed in the out-patient clinic: methodology and feasibility. Respir Care. 2014;59(4):531-7.

14. Peters DM, Fritz SL, Krotish DE. Assessing the reliability and validity of a shorter walk test compared with the 10-meter walk test for measurements of gait speed in healthy, older adults. J Geriatr Phys. 2013;36(1):24-30.

15. Karpman C, Benzo R. Gait speed as a measure of functional status in COPD patients. Int J Chron Obstruct Pulmon Dis. 2014;9:131520.

16. Venkataraman K, Amis K, Landerman LR, Caves K, Koh GC, Hoenig H. Teleassessment 
of gait and gait aids: validity and interrater Reliability. Phys Ther. 2020;100(4):708-17.

17. Li J. Rehabilitation management of patients with COVID-19: lessons learned from the first experience in China. Eur J Phys Rehabil Med. 2020;56(3):335-8.

18. Dolmage T, Rozenberg D, Malek N, Evans R, Goldstein R. saving time for patients with moderate to severe copd: endurance test speed set using usual and fast walk speeds. Chronic Obstr Pulm Dis J COPD Found. 2014;1(2):193-9.

19. Tino VYK, Morita AA, Bisca GW, Guzzi G, Machado FVC, Hernandes NA, et al. Which is the best protocol and cut-off point in the 4-metre gait speed test to discriminate exercise capacity in copd?. J Bras Pneumol. 2020;46(6):1-6.

20. Giavarina D. Understanding bland altman analysis. biochem Medica. 2015;25(2):14151.

21. Koo TK, Li MY. A guideline of selecting and reporting intraclass correlation coefficients for reliability research. J Chiropr Med. 2016;15(2):155-63.

22. Bohannon RW, Wang Y. Four-meter gait speed: normative values and reliability determined for adults participating in the NIH toolbox study. Arch Phys Med Rehabil. 2020;100(3):509-13. 